\title{
Effects of Culture Conditions on the Production of Inulinase by Kluyveromyces marxianus.
}

\author{
Marcia Luciana Cazetta ${ }^{1}$, Rubens Monti ${ }^{2}$ and Jonas Contiero ${ }^{1 *}$ \\ ${ }^{I}$ Departamento de Bioquímica e Microbiologia; Instituto de Biociências de Rio Claro; Universidade Estadual \\ Paulista; Av. 24 A 1515; 13506-900; Rio Claro - SP - Brasil. ${ }^{2}$ Departamento de Alimentos e Nutrição; Faculdade \\ de Ciências Farmacêuticas de Araraquara; Universidade Estadual Paulista; Araraquara - SP - Brasil
}

\begin{abstract}
The present study was conducted to investigate the influence of initial sucrose concentration, $p H$ and aeration rate on biomass and inulinase production by Kluyveromyces marxianus var. bulgaricus in a stirred batch reactor. Maximum inulinase activity $\left(15.29 \mathrm{UmL}^{-1}\right)$ was obtained at a sucrose concentration of $10 \mathrm{~g} \mathrm{~L}^{-1}, \mathrm{pH} 5.0$ and aeration rate of $1 \mathrm{vvm}$. The $20 \mathrm{~g} \mathrm{~L}^{-1}$ sucrose concentration was suitable for cell growth; however, enzymatic activity at this concentration was inhibited due to catabolic repression. The increase in aeration rate caused a reduction in enzyme activity with no relevant biomass increase.
\end{abstract}

Key words: Kluyveromyces marxianus var. bulgaricus, sucrose, inulinase, biomass, batch fermentation

\section{INTRODUCTION}

Inulinase is classified as a hydrolase and is designed as a 2,1- $\beta$-D-fructan fructanohydrolase (EC 3.2.1.7). Unlike an invertase, an inulinase is a non-specific $\beta$-fructofuranosidase and can hydrolyze 2,1-linked and 2,6-linked $\beta$-Dfructofuranose residue in fructan with the release of $\beta$-D-fructose. Natural inulinase substrates include inulin, sucrose and levan (Nagem et al., 2004). This enzyme has advantages over the use of invertase in food industries.

Interest in inulinase was aroused by with the discovery that this enzyme has the capability of hydrolyzing the inulin in practically pure fructose. This represents a great advantage over the conventional production of fructose from starch (potato or corn), which requires three enzymatic stages, including the action of $\alpha$-amylase, amyloglucosidase and glucose isomerase (Vandame and Derycke, 1983). This process produces $45 \%$ of the fructose solution due to the thermodynamic equilibrium between fructose and glucose.

Fructose can also be obtained by acid hydrolysis of inulin. However, this is not the method of choice for fructose production, as it results in the formation of difructose anhydrides, which are colored and have no sweetening capacity (Vandame and Derycke, 1983). Fructose synthesis by microbial inulinase, on the other hand, can yield up to 95 percent pure fructose in a single enzymatic step and promises to be a viable alternative (Vandame and Derycke, 1983; Gill et al., 2005; Zhang et al., 2005). Despite providing an adequate tool for overcoming the drawbacks, as the process is carried out under mild $\mathrm{pH}$ (4 to 5)

*Author for correspondence: jconti@ rc.unesp.br 
and temperatures $\left(35\right.$ to $\left.0^{\circ} \mathrm{C}\right)$, compared to the $\mathrm{pH}$ 2 and $75^{\circ} \mathrm{C}$ used in the chemical process (Kim and Rhee, 1989; Arruda and Vitolo, 1999; Sturm, 1999; Ettalibi and Baratti, 2001), this process has not yet been commercialized. Inulinases is also usually thermostable and commercially available for industrial applications (Chiang et al., 1997; Gupta et al., 1998).

Inulin is described as the most commonly used substrate in inulinase production. Inulin is a fructose polymer that consists of linear chains of $\beta-2,1$ linked D-fructofuranose molecules terminated at reduction and by a glucose residue attached through a sucrose-type linkage (Nakamura et al., 1995; Menne et al., 2000). However, due to its non-specificity, other substrates are successfully being used to produce inulinase by $K$. marxianus. Grootwassink and Flemming (1980) obtained high inulinase synthesis in a batch culture with a glucose, fructose and sucrose medium at low concentrations. In this type of process, Hewitt and Grootwassink (1984) found that maximum activity in sucrose was as high as in inulin. Rownhenrost $e t$ al. (1988) also obtained high inulinase production by $K$. marxianus CBS 6556 in a continuous sucrose-limited culture. The same occurred in experiments performed by Kushi et al. (2000) with $K$. marxianus var. bulgaricus. Thus, the aim of the present study work was to investigate the influence of culture condition on inulinase production by $K$. marxianus var. bulgaricus using sucrose as the carbon source in batch fermentation, as Brazil is an important sucrose producer and the industry that uses inverted sugar has a great interest in this research.

\section{MATERIAL AND METHODS}

\section{Microorganism}

Kluyveromyces. marxianus var. bulgaricus ATCC 16045 was obtained from the Department of Food Engineering of Campinas University UNICAMP. The stock culture was preserved frozen in cryogenic tubes with $20 \%$ glycerol. The culture was transferred to Petri dishes and maintained at $4^{0} \mathrm{C}$ until use

\section{Cell growth}

Biomass was determined by measuring the turbidity of the diluted sample at $600 \mathrm{~nm}$ using a standard absorbance curve against the dry cell mass.

\section{Enzymatic activity}

The enzymatic activity of the supernatant was determined following the procedures described by Suzuki et al. (1988), through the determination of reducing sugars formed by the incubation of $1 \mathrm{~mL}$ of enzyme in $2 \%$ sucrose, $0.05 \mathrm{M}$ citratephosphate buffer in $\mathrm{pH} 4.0$ at $50^{\circ} \mathrm{C}$, using 3,5dinitrosalisylic acid (Miller, 1959). Glucose $\left(1 \mathrm{~g} \mathrm{~L}^{-1}\right)$ was used for the standard curve. One unit of inulinase activity is defined as the amount of enzyme that hydrolyses $1 \mu \mathrm{mol}$ of sucrose per min under the above conditions.

\section{Total reducing sugars (TRS)}

Total reducing sugars (TRS) were determined following the hydrolysis of sucrose with $2 \mathrm{M} \mathrm{HCl}$ and neutralization with $2 \mathrm{M} \mathrm{NaOH}$ through 3,5dinitrosalisylic acid methods (Miller, 1959).

\section{Batch culturing}

Fermentations were carried out in 5-L fermenter containing $2-\mathrm{L}$ of culture medium. The fermentation medium was made up of $\mathrm{g} / \mathrm{L}$ sucrose (5, 10 and 20$), 5$ yeast extract, 10 peptone, 5 $\begin{array}{lllll}\mathrm{KH}_{2} \mathrm{PO}_{4}, & 1.5 & \mathrm{NH}_{4} \mathrm{Cl}, & 1.2 & \mathrm{KCl}\end{array}$ and 0.7 $\mathrm{MgSO}_{4} \cdot 7 \mathrm{H}_{2} \mathrm{O}$. The medium was sterilized in an autoclave at $121^{\circ} \mathrm{C}$ for $30 \mathrm{~min}$. The sucrose solution was sterilized separately and added aseptically to the culture medium. The $\mathrm{pH}$ was adjusted by adding orthophosphoric acid. Temperature was controlled at $30^{\circ} \mathrm{C}$ and the agitation rate was $300 \mathrm{rpm}$. The inoculum was prepared using the fermentation medium with $10 \mathrm{~g}$ $\mathrm{L}^{-1}$ of sucrose and maintained under agitation over night at $180 \mathrm{rpm}$ and $30^{\circ} \mathrm{C}$. Ten percent of this was transferred to the fermentation medium.

\section{RESULTS AND DISCUSSION}

\section{Influence of initial sucrose concentration}

In order to determine the effect of carbon source concentration on biomass and inulinase production, three sucrose concentrations were studied $\left(5,10\right.$ and $\left.20 \mathrm{~g} \mathrm{~L}^{-1}\right)$ in a $0.5 \mathrm{vvm}$ aerated reactor at $300 \mathrm{rpm}$ of agitation, $30^{\circ} \mathrm{C}$ and a working volume of $2 \mathrm{~L}$. The initial $\mathrm{pH}$ of the medium was adjusted to 3.5 . At $5 \mathrm{~g} \mathrm{l}^{-1}$ of initial sucrose concentration, the cell mass yield was 2.76 $\mathrm{g} \mathrm{l}^{-1}$. At $10 \mathrm{~g} \mathrm{l}^{-1}$ of sugar concentration, the cell growth reached $3.11 \mathrm{~g} \mathrm{l}^{-1}$ after $24 \mathrm{~h}$ of culture (Fig. 
1A). The biomass yield $\left(Y_{x / s}\right)$, however was higher in the $5 \mathrm{~g} \mathrm{l}^{-1}$ sucrose concentration $\left(0.491 \mathrm{~g} \mathrm{~g}^{-1}\right)$. In the $10 \mathrm{~g} \mathrm{l}^{-1}$ sucrose concentration, biomass yield was $0.318 \mathrm{~g} \mathrm{~g}^{-1}$ (Table 1).

Table 1 - Effect of sucrose concentrations on cell growth and enzymatic activity by K. marxianus var. bulgaricus at $30^{\circ} \mathrm{C}, 0.5$ vvm and $\mathrm{pH} 3.5$.

\begin{tabular}{lccc}
\hline \multicolumn{1}{c}{ Parameters } & \multicolumn{1}{c}{ Sucrose concentration $\left.\mathbf{~ ( g ~ l}^{\mathbf{- 1}}\right)$} \\
\hline Specific growth rate $\left(\mathrm{h}^{-1}\right)$ Growth phase & $\mathbf{5}$ & $\mathbf{1 0}$ & $\mathbf{2 0}$ \\
$\mathrm{Y}_{\mathrm{x} / \mathrm{s}}\left(\mathrm{g} \mathrm{g}^{-1}\right)$ & 0.336 & 0.318 & 0.298 \\
$\mathrm{Y}_{\mathrm{p} / \mathrm{s}}\left(\mathrm{U} \mathrm{ml}^{-1} \mathrm{~g}^{-1}\right)$ & 0.491 & 0.301 & 0.231 \\
$\mathrm{Y}_{\mathrm{p} / \mathrm{x}}\left(\mathrm{U} \mathrm{ml}^{-1} \mathrm{~g}^{-1}\right)$ & 0.642 & 0.615 & 0.070 \\
$\mathrm{Q}_{\mathrm{p}}\left(\mathrm{U} \mathrm{ml}^{-1} \mathrm{~h}^{-1}\right)$ & 1.309 & 2.044 & 0.302 \\
\hline
\end{tabular}

In cultures with a lower initial sucrose concentration $\left(5 \mathrm{~g} \mathrm{~L}^{-1}\right)$, enzymatic activity was $3.42 \mathrm{U} \mathrm{mL}^{-1}$ and at $10 \mathrm{~g} \mathrm{~L}^{-1} 6.51 \mathrm{U} \mathrm{mL}^{-1}$ after $24 \mathrm{~h}$ (Fig. 1B). This signified a higher inulinase yield $\left(\mathrm{Y}_{\mathrm{p} / \mathrm{x}}\right)$ for cultures at $10 \mathrm{~g} \mathrm{~L}^{-1}\left(2.044 \mathrm{U} \mathrm{mL}^{-1} \mathrm{~g}^{-1}\right.$ compared to $1.309 \mathrm{U} \mathrm{mL} \mathrm{g}^{-1}$ at a sucrose concentration of $5 \mathrm{~g} \mathrm{~L}^{-1}$ ). Inulinase yield for sucrose $\left(\mathrm{Y}_{\mathrm{p} / \mathrm{s}}\right)$ was similar for both cultures and productivity was also higher in the $10 \mathrm{~g} \mathrm{~L}^{-1}$ sucrose concentration (Table 1). When the sugar concentrations increase from 10 to $20 \mathrm{~g} \mathrm{~L}^{-1}$, the cell growth increased to $4.5 \mathrm{~g} \mathrm{~L}^{-1}$ after $24 \mathrm{~h}$, which represented an increase of $30 \%$. Nevertheless, the higher initial sucrose substrate concentration, three-fold decrease (1.92 $\mathrm{U} \mathrm{mL}^{-1}$ ) (Fig. 1B). Cazetta et al. (2005) observed the same results using yacon extract as substrate, in which $K$. marxianus show a decrease of about $14 \%$ in enzyme activity at concentrations above $40 \%$ (v/v) of the extract. Repression by substrate is common in the metabolism of many microorganisms. Wee et al. (2004) also observed a decrease in lactic acid yield produced by Enterococcus faecalis with an increase in sugar concentration in the medium.
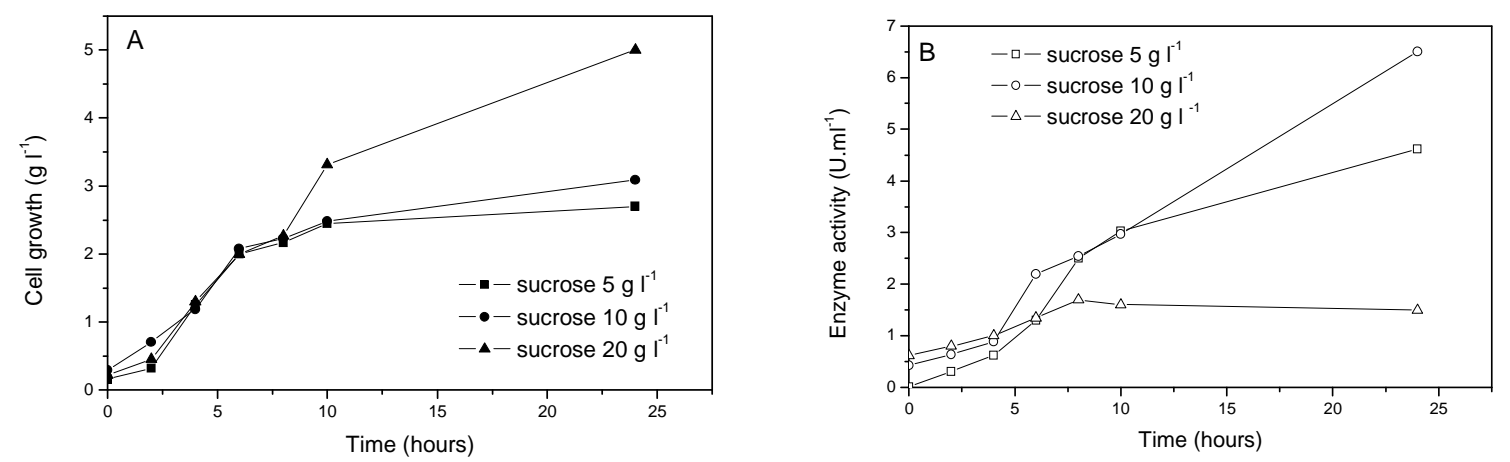

Figure 1 - Sucrose concentration effect on (A) cell growth and (B) enzymatic activity by $K$. marxianus var. bulgaricus: $\square 5 \mathrm{~g} \mathrm{l}^{-1} ; \bigcirc 10 \mathrm{~g} \mathrm{l}^{-1} ; \Delta \triangle 20 \mathrm{~g} \mathrm{l}^{-1}$.

The substrate was completely consumed after $6 \mathrm{~h}$ in the 5 and $10 \mathrm{~g} \mathrm{~L}^{-1}$ sucrose concentrations. At 20 $\mathrm{g} \mathrm{L}^{-1}$ of sucrose concentration, substrate was spent after $8 \mathrm{~h}$ of culturing (Fig. 2). Inulinase synthesis started together with cell growth and increased after 6 to $8 \mathrm{~h}$, when the amounts of total carbohydrate and reducing sugars were low, suggesting that the inulinase synthesis was suppressed by the high concentration of reducing sugars, as observed by Wei et al. (1998).

According to Parekh and Margaritis (1986), inulinase synthesis is controlled by catabolic repression and higher productions are reached at the end of the growth phase, apparently demonstrating that low concentrations of the carbon source are a prerequisite for inulinase 
synthesis. Pinheiro et al. (2000) also found that, at low concentrations, K. marxianus ATCC 10022 completely consumed the substrate, producing biomass and ethanol. However, in higher concentrations, this yeast only consumed $30 \%$ of the initial substrate, resulting in less productivity. Similar to the inulinase of Aspergillus niger A 42 (Öngen-Baysal et al., 1994), A. fumigatus (Kauer et al., 1999) and Streptomyces sp. (Gill et al., 2003), K. marxianus var. bulgaricus inulinase also appeared to be regulated by a double mechanism: increase by the substrate and repression by the product (glucose and fructose), as the activity decreased with sucrose concentrations above $10 \mathrm{~g}$ L-1, probably suppressed by reducing sugars.

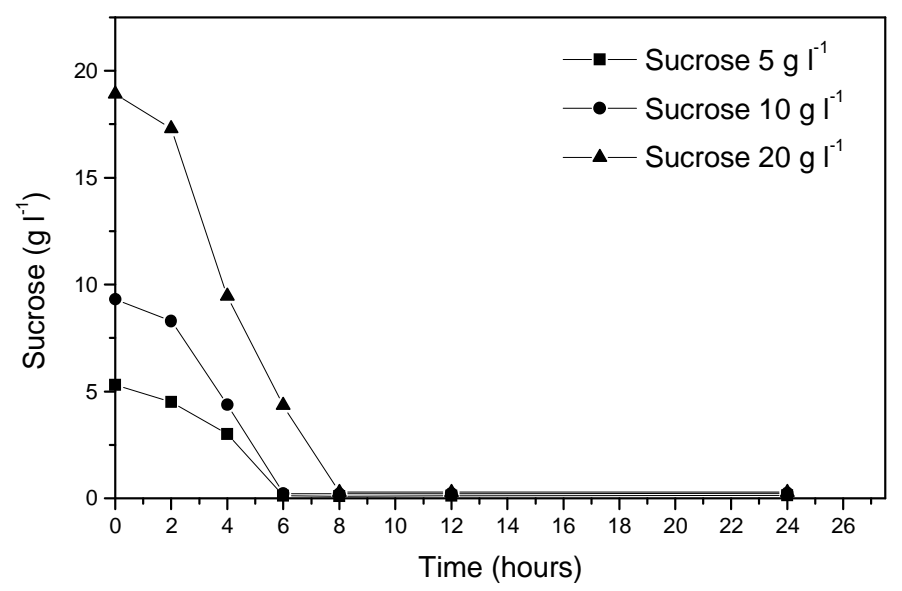

Figure 2 - Sucrose consumption by K. marxianus var. bulgaricus: $10 \mathrm{~g} \mathrm{l}^{-1} ; \mathbf{\Delta}$ : sucrose $20 \mathrm{~g} \mathrm{l}^{-1}$.

\section{Influence of $\mathbf{p H}$}

Figures 3A and 3B illustrate the effect of different culture $\mathrm{pH}$ values $(3.5,5.0$ and 6.0) on cell growth and inulinase activity by $K$. marxianus var. bulgaricus. The experiments were carried out in a reactor at $30^{\circ} \mathrm{C}, 0.5 \mathrm{vvm}$ aeration and agitation of $300 \mathrm{rpm}$. As seen in Fig. 3A, pH did not significantly influence cell growth, achieving $3.13 \mathrm{~g} \mathrm{~L}^{-1}$ at $\mathrm{pH} 3.5 ; 3.82 \mathrm{~g} \mathrm{~L}^{-1}$ at $\mathrm{pH} 5.0$ and 3.22 at $\mathrm{pH} 6.0$ However, the specific growth rate $(\mu)$ increased concomitantly with $\mathrm{pH}$ and gave the highest yield at $\mathrm{pH} 6.0\left(0.814 \mathrm{~h}^{-1}\right)$. For enzyme activity, however, the best $\mathrm{pH}$ was 5.0, reaching $13.14 \mathrm{U} \mathrm{ml}^{-1}$ after $10 \mathrm{~h}$ of fermentation, followed by $\mathrm{pH} 6.0$, with $11.75 \mathrm{U} \mathrm{ml}^{-1}$. $\mathrm{pH} 3.5$ was an unfavorable condition, as enzyme activity was 4.27 $\mathrm{U} \mathrm{mL}^{-1}$ after $12 \mathrm{~h}$ (Fig. 3B). Inulinase yield for sucrose $\left(\mathrm{Y}_{\mathrm{p} / \mathrm{s}}\right)$ and inulinase yield for biomass $\left(\mathrm{Y}_{\mathrm{p} / \mathrm{x}}\right)$, were similar for $\mathrm{pH} 5.0$ and $\mathrm{pH} 6.0$ (Table 2). Productivity $\left(\mathrm{Q}_{\mathrm{p}}\right)$ was higher at $\mathrm{pH} 5.0(1.31 \mathrm{U}$ $\mathrm{ml}^{-1} \mathrm{~h}^{-1}$ ) (Table 2). Pessoa and Vitolo (1999) obtained better results in a batch culture with inulin as the substrate $\left(26 \mathrm{U} \mathrm{ml}^{-1}\right)$ in the $\mathrm{pH}$ range from 3.5 to 5.0 for $K$. marxianus DMS 70106.

Table 2 - Effect of culture pH on cell growth and enzymatic activity by Kluyveromyces marxianus var. bulgaricus at $30^{\circ} \mathrm{C}, 300 \mathrm{rpm}$ and $0.5 \mathrm{vvm}$.

\begin{tabular}{|c|c|c|c|}
\hline \multirow{2}{*}{ Parameters } & \multicolumn{3}{|c|}{ pH } \\
\hline & 3.5 & 5.0 & 6.0 \\
\hline Specific growth rate $\left(\mathrm{h}^{-1}\right)$ Growth phase & 0.318 & 0.473 & 0.814 \\
\hline $\mathrm{Y}_{\mathrm{x} / \mathrm{s}}\left(\mathrm{g} \mathrm{g}^{-1}\right)$ & 0.330 & 0.452 & 0.413 \\
\hline $\mathrm{Y}_{\mathrm{p} / \mathrm{s}}\left(\mathrm{U} \mathrm{ml}^{-1} \mathrm{~g}^{-1}\right)$ & 0.711 & 1.573 & 1.547 \\
\hline$Y_{\mathrm{p} / \mathrm{x}}\left(\mathrm{U} \mathrm{ml}^{-1} \mathrm{~g}^{-1}\right)$ & 2.155 & 3.781 & 3.743 \\
\hline $\mathrm{Q}_{\mathrm{p}}\left(\mathrm{U} \mathrm{ml}^{-1} \mathrm{~h}^{-1}\right)$ & 0.271 & 1.315 & 1.176 \\
\hline
\end{tabular}



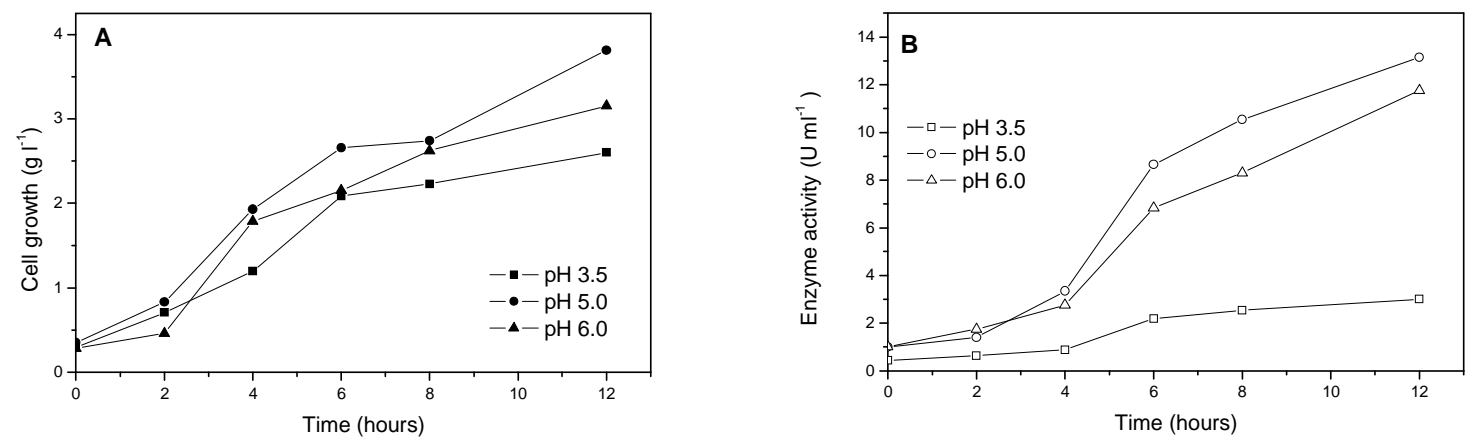

Figure 3 - (A) Cell growth and (B) enzymatic activity of $K$. marxianus var. bulgaricus at $30^{\circ} \mathrm{C}$ and 0.5 vvm and different pH levels. $\square \square: \mathrm{pH} 3.5 \bigcirc \mathrm{O}: \mathrm{pH} 5.0 \Delta \triangle$ : $\mathrm{pH}$ 6.0.

\section{Effect of aeration rate}

Figures 4A and 4B illustrate the cell growth and enzymatic activity by $K$. marxianus at different aeration rates (vvm): 0.2, 0.5, 1.0, 2.0 and 3.0. Fermentations were performed at $\mathrm{pH} 5.0,30^{\circ} \mathrm{C}$ and $300 \mathrm{rpm}$. Cell growth was generally positively affected by the aeration increase. The lowest growth was observed at $0.2 \mathrm{vvm}\left(1.83 \mathrm{~g} \mathrm{l}^{-1}\right)$. Cell growth was similar at both $0.5 \mathrm{vvm}$ and $1.0 \mathrm{vvm}$, reaching about $4.0 \mathrm{~g} \mathrm{l}^{-1}$. Higher cell growth was obtained at 2 and $3 \mathrm{vvm}\left(5.65\right.$ and $5.43 \mathrm{~g} \mathrm{~L}^{-1}$, respectively). The increase in aeration rate was accompanied by increase of specific growth rate $(\mu)$ from 0.158 to $0.270 \mathrm{~h}^{-1}$. The same occurred for the maximum values of biomass yield $\left(\mathrm{Y}_{\mathrm{x} / \mathrm{s}}\right)$ (Table $3)$. Working with two strains of $K$. marxianus $(K$. marxianus ATCC 10022 and CBS 7894), Pinheiro et al. (2000) observed that a small 2-bar increase in air pressure led to a three-fold increase in biomass yield, whereas further increase in air pressure did not lead to a significant increase in biomass yield.
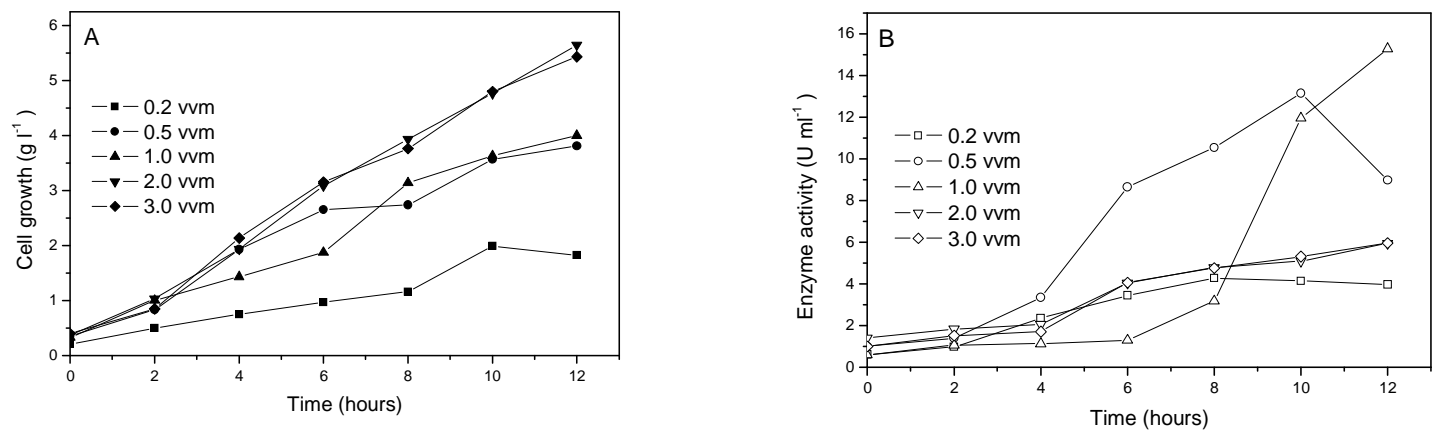

Figure 4 - Cell growth (A) and enzymatic activity (B) of Kluyveromyces marxianus var. bulgaricus at different aeration rates. $\square 0.2 \mathrm{vvm} ; \bigcirc 0.5 \mathrm{vvm} ; \boldsymbol{\Delta} \triangle 1.0 \mathrm{vvm}$; $\nabla \nabla 2.0 \mathrm{vvm} ; \diamond \diamond 3.0 \mathrm{vvm}$.

However, enzyme activity decreased with the increase in aeration. The highest enzymatic activity was achieved at $1.0 \mathrm{vvm}\left(15.29 \mathrm{U} \mathrm{ml}^{-1}\right)$ after $12 \mathrm{~h}$, followed by $0.5 \mathrm{vvm}\left(13.15 \mathrm{U} \mathrm{ml}^{-1}\right)$. At 2 and 3 vvm, enzymatic activity decreased significantly, achieving about $6.0 \mathrm{U} \mathrm{ml}^{-1}$ after $12 \mathrm{~h}$
(Fig. 4B). The highest values for inulinase yield for sucrose $\left(\mathrm{Y}_{\mathrm{p} / \mathrm{s}}\right)$, inulinase yield for biomass $\left(\mathrm{Y}_{\mathrm{p} / \mathrm{x}}\right)$ and productivity $\left(\mathrm{Q}_{\mathrm{p}}\right)$ were obtained at 0.5 and $1.0 \mathrm{vvm}$. The $0.2 \mathrm{vvm}$ aeration was an insufficient rate, showing about $4.0 \mathrm{U} \mathrm{mL}^{-1}$ of enzyme activity (Table 3 ). 
Table 3 - Effect of aeration rate on cell growth and enzymatic activity by Kluyveromyces marxianus var. bulgaricus at $30^{\circ} \mathrm{C}, 300 \mathrm{rpm}$ and $0.5 \mathrm{vvm}$.

\begin{tabular}{lccccc}
\multicolumn{1}{c}{ Parameters } & \multicolumn{5}{c}{ Aeration (vvm) } \\
\cline { 2 - 6 } & $\mathbf{0 . 2}$ & $\mathbf{0 . 5}$ & $\mathbf{1 . 0}$ & $\mathbf{2 . 0}$ & $\mathbf{3 . 0}$ \\
\hline Specific growth rate $\left(\mathrm{h}^{-1}\right)$ Growth phase & 0.158 & 0.236 & 0.227 & 0.265 & 0.270 \\
$\mathrm{Y}_{\mathrm{x} / \mathrm{s}}\left(\mathrm{g} \mathrm{g}^{-1}\right)$ & 0.167 & 0.452 & 0.370 & 0.676 & 0.663 \\
$\mathrm{Y}_{\mathrm{p} / \mathrm{s}}\left(\mathrm{U} \mathrm{ml}^{-1} \mathrm{~g}^{-1}\right)$ & 0.350 & 1.573 & 1.479 & 0.582 & 0.653 \\
$\mathrm{Y}_{\mathrm{p} / \mathrm{x}}\left(\mathrm{U} \mathrm{ml}^{-1} \mathrm{~g}^{-1}\right)$ & 2.089 & 3.781 & 4.003 & 0.861 & 0.984 \\
$\mathrm{Q}_{\mathrm{p}}\left(\mathrm{U} \mathrm{ml}^{-1} \mathrm{~h}^{-1}\right)$ & 0.331 & 1.3146 & 1.274 & 0.496 & 0.496 \\
\hline
\end{tabular}

Silva-Santisteban and Maugeri Filho (2005) described a similar behavior in experiments using K. marxianus var. bulgaricus. The authors did not obtain an increase in inulinase yield with an increase in aeration rate from 1 to $2 \mathrm{vvm} \mathrm{(89}$ and $84 \mathrm{IU} \mathrm{mL}^{-1}$, respectively) after $72 \mathrm{~h}$. In fed-batch fermentation with sucrose as the substrate, Cazetta (2005) also observed higher inulinase production at 1 vvm. Cristiani-Urbina et al. (2005) observed cellular metabolism alteration from oxidative to a mix oxidative-fermentative in aerated cultures of some $K$ fragilis strains, resulting in the production of metabolites such as alcohols, aldehydes and esters, which reduced biomass production.

In conclusion, the best condition for inulinase production in batch-reactor fermentation was $10 \mathrm{~g}$ $1^{-1}$ of initial sucrose concentration, $\mathrm{pH} 5.0$ and 1 vvm aeration rate.

\section{NOMENCLATURE}

$\mathrm{Y}_{\mathrm{X} / \mathrm{s}}$ - sucrose biomass yield $\left(\mathrm{g} \mathrm{g}^{-1}\right)$

$\mathrm{Y}_{\mathrm{p} / \mathrm{s}}$ - sucrose inulinase yield $\left(\mathrm{U} \mathrm{mL}^{-1} \mathrm{~g}^{-1}\right)$

$\mathrm{Y}_{\mathrm{p} / \mathrm{x}}$-inulinase biomass yield $\left(\mathrm{U} \mathrm{mL}^{-1} \mathrm{~g}^{-1}\right)$

$\mathrm{Q}_{\mathrm{p}}$ - volumetric enzyme production $\left(\mathrm{U} \mathrm{mL}^{-1} \mathrm{~h}^{-1}\right)$

$\mu$ - specific growth rate $\left(\mathrm{h}^{-1}\right)$

$\mathrm{rpm}-$ revolutions per minute $\left(\mathrm{min}^{-1}\right)$

\section{ACKNOWLEDGEMENTS}

The authors are grateful to CNPq-Brazil Agency and Sao Paulo State University-Unesp for financial support to develop this work.

\section{RESUMO}

O estudo foi conduzido para investigar a influência da concentração inicial da sacarose, a taxa da aeração e do $\mathrm{pH}$ na biomassa e na produção da inulinase pela Kluyveromyces marxianus var. bulgaricus em um reator em batelada. A máxima atividade de inulinase, $15.29 \mathrm{UmL}^{-1}$, foi obtida na concentração de $10 \mathrm{~g} \mathrm{~L}^{-1}$ de sacarose, no pH $5.0 \mathrm{e}$ na taxa da aeração de $1 \mathrm{vvm}$. A concentração de sacarose de $20 \mathrm{~g} \mathrm{~L}^{-1}$ foi apropriada para o crescimento celular, porém nesta concentração a atividade enzimática foi inibida, devido a repressão catabólica. O aumento na taxa da aeração propiciou redução da atividade enzimática, ao mesmo tempo em que não houve aumento considerável do biomassa.

\section{REFERENCES}

Nagem, RAP, Rojas, AL, Golubev AM, Korneeva OS, Eneyskaya EV, Kulminskaya AA, Neustroev KN, Polikarpov (2004), I. Crystal structure of exoinulinase from Aspergillus awamori: the enzyme fold and structural determinants of substrate recognition. $\mathbf{J}$ Mol Biol; 344, 471-480.

Vandame E, Derycke D. (1983), Microbial inulinases: Fermentation process, properties and applications. Advances Appl Microbiol; 29, 139-176.

Gill PK, Manhas RK, Singh P. (2005), Comparative analysis the thermostability of extracellular inulinase activity from Aspergillus fumigatus with commercially available (Novozyme) inulinase. Bioresour Technol. Avaiable on line: $<$ http://www.sciencedirect.com.

Zhang 1, Zhao C, Ohta WY, Wang, Y. (2005), Inhibition of glucose on an exoinulinase from Kluyveromyces marxianus expressed in Pichia pastoris. Proc Biochem; 40, 1541-1545.

Kim CH, Rhee SK. (1989), Fructose production from Jerusalem artichoke by inulinase immobilized on chitin. Biotechnol Lett; 11, 201-206.

Arruda LM, Vitolo M. (1999), Charachterization of invertase entrapped into calcium alginate beads. Appl Biochem Biotechnol; 8, 23-33.

Sturm A. (1999), Invertases: primary structures, functions and roles in plant development and sucrose partitioning. Plant Physiol; 121, 1-7.

Ettalibi M, Baratti JC. (2001), Sucrose hydrolysis by thermostable immobilized inulinases from 
Aspergillus ficuum. Enzyme Microb Technol; 28, 596-601.

Chiang CJ, Lee WC, Sheu DC, Duan KJ. (1997), Immobilization of beta-fructofuranosidades from Aspergillus on methacrylamide-based polymeric beads for production of fructooligosaccharides. Biotechnol Prog; 13, 577-582.

Gupta AK, Rathore P, Kaur N. (1998), A $\mathrm{HgCl}_{2}$ insensitive and thermally stable inulinase from Aspergillus oryzae. Phytochem; 49 (1), 55-58.

Nakamura T, Ogata Y, Shitara A, Nakamura A, Ohta K. (1995). Continuous production of fructose syrups from inulin by immobilized inulinase from Aspegillus niger mutant 817. J Ferment. Bioeng; 80 (2), 164169.

Menne E, Guggenbuhl N, Roberfroid M. (2000), Fntype chicory inulin hydrolysate has a prebiotic effect in humans. J Nutr; 130, 1197-1199.

Grootwassink JWD, Fleming SE. (1980), Non-specific $\beta$-frutofuranosidase (inulinase) from Kluyveromyces fragilis: batch and continuous fermentation, simple recovery method and some industrial properties. Enzyme Microb Technol; 2, 45-53.

Hewitt GM, Grootwassink, WD. (1984), Simultaneous production of inulase and lactase in batch and continuous cultures of Kluyveromyces fragilis. Enzyme Microb Technol; 6, 263-270.

Rouwenhorst RJ, Visser LE, Van der Baan AA, Scheffers WA, van Dijken JP. (1988), Production, distribution and kinetic properties of inulinase in continuous cultures of Kluyveromyces marxianus CBS 6556. Appl Environ Microbiol; 54, 1131-1137.

Kushi RT, Monti R, Contiero J. (2000), Production, purification and characterization of an extracellular inulinase from Kluyveromyces marxianus var. bulgaricus. J Ind Microbiol Biotechnol., 25, 63-69.

Suzuki H, Ozawa Y, Maeda H. (1988), Studies of water-insoluble yeast invertase. Agric Biol Chem; 30, 807-812.

Miller GL. (1959), Use of dinitrosalicylic acid reagent for determination of reducing sugars. Anal Chem; 31 (3), 426-429.

Cazetta ML, Martins, PMM, Monti R, Contiero J. (2005), Yacon (Polymnia sanchifolia) extract as a substrate to produce inulinase by Kluyveromyces marxianus var. bulgaricus. J Food Eng; 66, 301-305.

Wee Y J, Kim JN, Yun JS, Ryu HW. (2004), Utilization of sugar molasses for economical L(+)-lactic acid production by batch fermentation of Enterococcus faecalis. Enzyme Microbiol Technol; 35, 568-573.
Wei W, Zheng Z, Liu Y, Zhu X. (1998), Optimizing the culture conditions for higher inulinase production by Kluyveromyces sp. Y-85 and scaling-up fermentation; 86 (4), 395-399.

Parekh S, Margaritis A. (1986), Production of inulinase ( $\beta$ - Fructan Fructanohydrolase) by Kluyveromyces marxianus. Agricultural Biol Chem; 50 (4), 1085 1087.

Pinheiro R, Belo I, Mota M. (2000), Air pressure effects on biomass yield of two different Kluyveromyces strains. Enzyme Microbiol Technol; 26, 756-762.

Öngen-Baysal G, Sukan SS, Vassilev N. (1994), Production and properties of inulinase from Aspergillus niger. Biotechnology Letters; 16 (3), 275280.

Kauer A, Sharma D, Harchand RK, Singh P, Bhullar SS, Kaur A. (1999), Production of a thermostable extracellular inulinase by Aspergillus fumigatus. Indian J Microbiol; 39, 99-103.

Gill P K, Sharma AD, Harchand R K, Singh P. (2003), Effect of media supplements and culture conditions on inulinase production by an actinomycete strain. Bioresource Technol; 87, 359-362.

Pessoa Jr A, Vitolo M. (1999), Inulinase from Kluyveromyces marxianus: culture medium composition and enzyme extraction. Brazilian J Chem Eng; 16 (6), 1-14.

Silva-Santisteban BOY, Maugeri Filho F. (2005), Agitation, aeration and shear stress as key factors in inulinase production by Kluyveromyces marxianus. Enzyme Microbiol Technol; 36, 717-724.

Cazetta ML. (2005), Produção de biomassa e inulinase por Kluyveromyces marxianus var. bulgaricus: influência das condições de cultivo. Tese (Doutorado) Depratamento de Bioquímica e Microbiologia, Universidade Estadual Paulista; 2005. Rio Claro Universidade Estadual Paulista; 113 p.

Cristiani-Urbina E, Netzahuatl-Muñoz AR, ManriquezRojas FJ, Juárez-Ramírez C, Ruiz-Ordaz N, GalínderMayer J. (2000), Batch and fed-batch cultures for a treatment of whey with mixed yeast cultures. Proc Biochem; 35, 649-657. 